\title{
Copepod egg production and hatching success is reduced by maternal diets of a non-neurotoxic strain of the dinoflagellate Alexandrium tamarense
}

\author{
Adrianna Ianora ${ }^{1, *}$, Jefferson T. Turner ${ }^{2}$, Francesco Esposito ${ }^{1}$, Ylenia Carotenuto ${ }^{1}$, \\ Giuliana d'Ippolito ${ }^{1,3}$, Giovanna Romano ${ }^{1}$, Angelo Fontana ${ }^{3}$, Cástor Guisande ${ }^{4}$, \\ Antonio Miralto ${ }^{1}$
}

\author{
${ }^{1}$ Ecophysiology Laboratory, Stazione Zoologica A. Dohrn, Villa Comunale 80121 Naples, Italy \\ ${ }^{2}$ School for Marine Science and Technology, University of Massachusetts Dartmouth, 706 South Rodney French Boulevard, \\ New Bedford, Massachusetts 02744, USA \\ ${ }^{3}$ Istituto di Chimica Biomolecolare (ICB) del CNR, Via Campi Flegrei 34, 80078 Pozzuoli (Naples), Italy \\ ${ }^{4}$ Facultad de Ciencias del Mar, Universidad de Vigo, Lagoas-Marcosende, 36200 Vigo, Spain
}

\begin{abstract}
A unialgal diet of a non-neurotoxic strain of the dinoflagellate Alexandrium tamarense strongly modified egg production and hatching success in the copepod Temora stylifera, even though grazing rates were relatively constant over time. Both exponential and stationary cultures of $A$. tamarense reduced egg production and hatching success, but the effect of stationary cultures on hatching success was dramatic, with egg viability dropping to $0 \%$ after $24 \mathrm{~h}$ of feeding. HPLC analyses revealed that the $A$. tamarense clone was non-neurotoxic, with a mean toxin content of about $0.005 \mathrm{fmol}$ per cell, indicating that adverse effects were not due to saxitoxins or neosaxitoxins. ${ }^{1} \mathrm{H}-\mathrm{NMR}$ analyses also revealed that diatom-derived PUSCAs (polyunsaturated short-chain aldehydes) were not responsible for reduced hatching rates, since these compounds were absent in $A$. tamarense as compared to the diatom Skeletonema costatum. Extracts of $A$. tamarense and the diatom-derived PUSCA 2-trans-4-trans-decadienal were also assessed in terms of biological effects on sea urchin embryo cell divisions. A. tamarense did not show anti-mitotic properties, as extracts did not block first-cell cleavage compared to decadienal. However, A. tamarense extracts did block fertilization success when sea urchin oocytes were first incubated for $30 \mathrm{~min}$ in extracts and then fertilized, as opposed to $S$. costatum extracts, which did not affect normal elevation of the fertilization membrane. This is the first report that dinoflagellates produce antiproliferative compounds, other than PUSCAs, that can potentially reduce copepod egg production and hatching success.
\end{abstract}

KEY WORDS: Dinoflagellate $\cdot$ Copepods $\cdot$ Egg production $\cdot$ Hatching success $\cdot$ Antiproliferate compounds Resale or republication not permitted without written consent of the publisher

\section{INTRODUCTION}

Numerous species of diatoms negatively affect copepod reproduction, not only through reduced fecundity, but also and especially through reduced egg hatching success (reviewed by Ianora et al. 2003). Reduced egg viability has recently been linked to the presence of polyunsaturated short-chain aldehydes (PUSCAs) in diatoms that block copepod embryogenesis, thereby acting as anti-herbivory agents (Miralto et al. 1999). These aldehydes are synthesized from polyunsatu- rated $\mathrm{C}_{16}$ and $\mathrm{C}_{20}$ fatty acids, which are widespread in this algal class (Pohnert 2000, Pohnert et al. 2002, d'Ippolito et al. 2002). When diatoms become damaged due to feeding, they produce aldehyde within seconds after cell disruption, similar to the wound reaction in higher plants (Rosahl 1996).

In addition to effects on egg hatching, certain diatom diets induce teratogenic effects (i.e. 'birth defects') in newly hatched copepod nauplii, which then have asymmetrical bodies and reduced numbers of feeding appendages (e.g. Poulet et al. 1995). These nauplii die 
within a few hours after hatching. Copepods may ameliorate the negative effects of diatom diets on egg hatching by feeding on alternative food items in a mixed diet (Turner et al. 2001). When this occurs, the effect is not neutralized, but mitigated so that a portion of the eggs develops to hatching.

There is also field evidence that diatom blooms negatively impact copepod egg hatching success. Miralto et al. (2003) showed that during diatom blooms in the northern Adriatic Sea, copepod egg production rates were high, but only $10 \%$ of the eggs produced by Acartia clausi and Calanus helgolandicus were viable. This was compared to post-bloom conditions, when egg production rates were lower, but hatching success was $90 \%$. Mesocosm experiments from the Norwegian coast indicated a drop of $>95 \%$ in reproductive success of C. helgolandicus during a diatom bloom, even though feeding rates were high and alternate prey were available (Nejstgaard et al. 2001). Ban et al. (2000) reported a high incidence (20 to $40 \%$ ) of abnormal nauplii of Pseudocalanus newmani during a diatom bloom in the Sea of Japan, and concluded that the deformities of copepod nauplii were due to maternal feeding on diatoms. In contrast, other studies have not found a negative relationship between hatching viability and diatom concentrations (Ohman \& Hirche 2001, Irigoien et al. 2002). This suggests that not all diatom blooms are toxic, toxic effects are lessened by ingestion of co-occurring non-diatom foods, and/or that some copepod species may have evolved mechanisms to detoxify diatom aldehydes in a continuing coevolutionary arms race between plant defenses and animal responses.

Although evidence for diatom chemical defenses against reproductive success of their grazers continues to accumulate (Ianora et al. 2004), it is unclear whether similar mechanisms are found in other phytoplankton groups such as dinoflagellates. Dinoflagellates produce potent neurotoxins that cause shellfish poisoning and adverse effects on grazers such as zooplankton, and these toxins can be transported up the food chain to higher trophic levels (Turner \& Tester 1997). However, the often-assumed antipredation role of dinoflagellate neurotoxins is complicated by equivocal observations that these compounds often have no clear adverse effects on zooplankton grazers (Turner et al. 1998a). These toxins may have evolved primarily for other roles that benefit dinoflagellates, such as nitrogen storage, bioluminescence, chromosome structural organization, pheromones for induction of sexuality, or they may simply be vestigial products of archaic pathways for nucleic acid biosynthesis (Cembella 1998). Some dinoflagellate neurotoxins may also be produced by bacterial endosymbionts, rather than by the dinoflagellates themselves (Doucette et al. 1998). Thus, dinoflagellate toxins may be only coincidentally toxic to some phytoplankton grazers.

When dinoflagellate toxins do have adverse effects on consumers, these are mostly neurological effects through sodium channel activation (brevetoxins), sodium channel blockage (saxitoxins) or neuronal depolarisation (domoic acid) (reviews in Baden \& Trainer 1993, Turner \& Tester 1997, Turner et al. 1998a). Direct adverse neurological effects on grazers such as copepods include reduced ingestion, regurgitation, lethargy or death (Huntley et al. 1986, 1987, Sykes \& Huntley 1987, Uye \& Takamatsu 1990, Teegarden 1999). There are also reports of adverse effects on reproduction, such as reduced egg production rates (Dutz 1998), or reduced egg hatching success (Turner et al. 1998a,b, Ianora et al. 1999, Frangópulos et al. 2000, Guisande et al. 2002). However, it is still unclear whether these adverse effects on copepod reproduction are due to neurotoxins that also affect mitotic divisions, or whether the adverse effects are caused by other unidentified compounds.

Here we further explore the negative effects of dinoflagellate diets on copepod reproduction. Our working hypothesis was that the dinoflagellates could produce deleterious compounds other than the described neurotoxins. Accordingly, we examined effects of non-neurotoxic clones of the dinoflagellate Alexandrium tamarense on filtration and ingestion rates, egg production rates, and egg hatching success in the copepod Temora stylifera from the Gulf of Naples, Italy.

\section{MATERIALS AND METHODS}

Grazing experiments. Grazing experiments were performed in the summer of 2000 with adult females of Temora stylifera collected from the Gulf of Naples and transferred to the laboratory within $1 \mathrm{~h}$ of collection. We added 5 females to each of triplicate experimental jars containing $500 \mathrm{ml}$ food suspensions. A control jar with no copepods was treated in the same way as the experimental jars, and an initial sample of each food suspension was preserved with Lugol's solution at the beginning of each experiment. Food suspensions were mixtures of $0.45 \mu \mathrm{m}$ filtered seawater (FSW) and the non-neurotoxic dinoflagellate Alexandrium tamarense in exponential (EXPO) growth at mean ( \pm SD) concentrations of $1.8( \pm 0.5) \times 10^{3}$ cells ml ${ }^{-1}$. Equivalent carbon concentrations based on cell size (length: $34.2 \mu \mathrm{m}$; width: $32.2 \mu \mathrm{m}$ ) were $1848 \mathrm{pgC} \mathrm{cell}{ }^{-1}$, determined using the formulae of Strathman (1967).

Alexandrium tamarense (strain number FE 107; isolated from the Gulf of Naples by F.E. in 1999) was cultured in 21 glass jars filled with $0.22 \mu \mathrm{m}$ FSW enriched with $k$ medium (Keller et al. 1987) at $20^{\circ} \mathrm{C}$ and on a 
12:12 h dark:light cycle. Food suspensions were prepared daily by performing a cell count in stock cultures and adjusting the concentration by dilution with FSW. Female Temora stylifera were transferred daily by gently pouring them into bowls, and then re-pipetting them into freshly prepared food suspensions. After removal of copepods from food suspensions, aliquots of $50 \mathrm{ml}$ of each food suspension were preserved in $2 \%$ Lugol's solution. Phytoplankton cell numbers in preserved aliquots were counted in Sedgwick-Rafter cells; at least 400 cells were counted in all cases, ensuring $\pm 10 \%$ precision (Guillard 1973). Ingestion and filtration rates were determined from differences in phytoplankton cell concentrations in initial, control and experimental suspensions using the formulae of Frost (1972).

Numerous females were kept in reserve and exposed to the same conditions as experimental ones, including daily switching to fresh food suspensions. Dead experimental females were removed and replaced every day with females from the reserve treatment. Grazing rates for dead copepods were calculated assuming that they had lived for half the experiment. Experimental incubations lasted 22.3 to $24.9 \mathrm{~h} \mathrm{~d}^{-1}$; incubation bottles were mounted on a rotating wheel $(0.5 \mathrm{rpm})$ in a controlled temperature room at $20^{\circ} \mathrm{C}$ with a $12: 12 \mathrm{~h}$ dark:light cycle. Grazing experiments were repeated daily with the same copepods being placed in new food suspensions for 13 consecutive days.

Egg production and hatching experiments. Daily egg production and hatching success in Temora stylifera were determined by incubating female and male couples $(\mathrm{n}=15)$ as individual pairs in $100 \mathrm{ml}$ crystallizing dishes containing ambient seawater. Egg production rates, fecal pellet production rates, and hatching success were determined $24 \mathrm{~h}$ later. Only couples with high initial egg production rates and hatching success were maintained for successive experiments. These couples were then transferred to new containers with $100 \mathrm{ml}$ of $0.45 \mu \mathrm{m}$ FSW enriched with Alexandrium tamarense in the exponential (EXPO) or stationary (STAT) growth phases. In a first set of experiments, final cell concentrations of EXPO or STAT growth

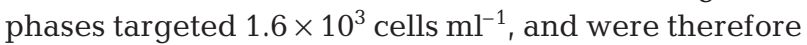
similar to cell concentrations used in grazing experiments. In a second and a third set of experiments, final cell concentrations of EXPO or STAT growth phases were $2 \times$ and $3 \times$ the initial concentrations.

Thereafter, all couples were transferred each day to new containers with fresh cultures provided at EXPO $1 \times, 2 \times$ and $3 \times$ or STAT $1 \times, 2 \times$ and $3 \times$ initial cell concentrations. A daily record was kept of egg production, egg viability and number of fecal pellets and spermatophores. Hatching success was determined $48 \mathrm{~h}$ after spawning by adding $95 \%$ ethyl alcohol to containers and counting the number of hatched nauplii once they had settled to container bottoms. A daily record was also kept of the number of cannibalised eggs (identified by crumpled egg membranes: see Turner et al. 2001). There were very few cannibalised eggs, since copepods were well fed. All experiments were run for $14 \mathrm{~d}$ or until death of the female. If males died before females, they were substituted with freshly caught males. This was done to ensure that non-viable egg production was not due to an absence of remating. Parallel control experiments were run with the non-toxic dinoflagellate Prorocentrum minimum in the stationary growth phase with final concentrations $\left(7 \times 10^{3}\right.$ cells $\mathrm{ml}^{-1} ; 177.1 \mathrm{pgC} \mathrm{cell}^{-1}$ ) representing about half the carbon content of Alexandrium tamarense $(1 \times)$; culture media and culture conditions were the same as above. This dinoflagellate species was chosen as control since it promotes high egg production and egg hatching success in Temora stylifera (Turner et al. 2001, Ceballos \& Ianora 2003); 16 T. stylifera couples were incubated as above and a daily record was kept of egg production, hatching success, fecal pellet production and percentage of survival with this diet. All experimental animals were kept in a temperature-controlled chamber at $20^{\circ} \mathrm{C}$ and on a 12:12 h dark:light cycle.

Toxin analyses. To estimate cell toxin content, Alexandrium tamarense cells were cultured in gently aerated 101 carboys under the conditions described above. Cells in exponential and stationary growth phases were collected on $47 \mathrm{~mm}$ diameter Whatman $\mathrm{GF} / \mathrm{F}$ filters, stored at $-20^{\circ} \mathrm{C}$ in ultracentrifuge plastic tubes and lyophilised. Subsequently, $0.5 \mathrm{ml}$ of $0.05 \mathrm{M}$ acetic acid was added to the lyophilised material and the sample was homogenised using a pipette tip adapted to fit the shape of the vial. The sample was twice shaken followed by freezing. Finally, the extract was centrifuged at $4000 \mathrm{rpm}(400 \times g)$ for $10 \mathrm{~min}$ twice, after which $200 \mu \mathrm{l}$ of the supernatant was carefully collected with a Hamilton syringe, and stored at $-20^{\circ} \mathrm{C}$.

Analysis of paralytic shellfish poisoning (PSP) toxins (C1-4, GTX1-6, neoSTX, STX, dcSTX) by HPLC with fluorescent detection was performed following a modification of the method of Oshima et al. (1989) described by Franco \& Fernández (1993). Toxin profiles were determined by injections of an extract of $>250000$ cells. Verification of the presence of toxins Cs, GTX 5 and GTX 6 was done by boiling the sample with an equal volume of $0.4 \mathrm{~N} \mathrm{HCl}$ for $15 \mathrm{~min}$. The eluent of the first isocratic was $95 \% 0.5 \mathrm{mM}$ sodium octansulfonate in $10 \mathrm{mM}$ ammonium phosphate (pH 7.2) $5 \%$ acetonitrile, for the separation of NeoSTX, dcSTX and STX. The eluent for the second isocratic was $1.5 \mathrm{mM}$ sodium octansultonate in $10 \mathrm{mM}$ ammonium phosphate ( $\mathrm{pH} 7$ ) 5\% acetonitrile, for the separation of GTXs and dcGTXs. Toxins from the National Research Council of Canada (Halifax) were used as standards. 
Toxicity, in saxitoxin equivalents (STXeq), was calculated from HPLC chromatograms, by multiplying toxin concentrations by a toxin-specific conversion factor from Oshima (1995); the conversion factor is based upon empirical mouse bioassay data determined using purified standards, and assuming the conversion factor of 1 mouse unit $(\mathrm{MU})=0.23 \mu \mathrm{g}$ STXeq for the ddy mouse strain: 567.6 (GTX1), 205.2 (GTX2), 364.3 (GTX3), 414.7 (GTX4), 36.8 (GTX5), 371.9 (GTX6), 3.45 (C1), 54.9 (C2), 7.6 (C3), 32.9 (C4), 571.1 (STX), 527.8 (neoSTX), 293 (dcSTX).

Analysis of amino acids and fatty acids. To estimate their amino acid and fatty acid composition, Alexandrium tamarense cells were cultured in $10 \mathrm{l}$ carboys at $17.5^{\circ} \mathrm{C}$ and on a $12: 12 \mathrm{~h}$ dark:light cycle. Cells in exponential growth phase were collected on precombusted $13 \mathrm{~mm}$ diameter Whatman GF/F filters and stored at $-20^{\circ} \mathrm{C}$ in ultracentrifuge plastic tubes.

Amino acid composition was analysed by HPLC (HPLC) using a Waters Alliance System, a Waters 474 scanning fluorescence detector and a Waters $150 \times$ $3.9 \mathrm{~mm}$ Nova-Pack C18 column following the method described by Van Wandelen \& Cohen (1997). Amino acid standard H NCI0180 Pierce was used for the identification and quantification of amino acids. We analyzed 15 amino acids: aspartic acid, serine, glutamic acid, glycine, histidine, arginine, threonine, alanine, proline, tyrosine, valine, lysine, isoleucine, leucine and phenylalanine.

Total lipids were extracted by the method of Folch et al. (1957). The lipid extract was quantified gravimetrically and kept in a stoppered vessel under nitrogen atmosphere at $-30^{\circ} \mathrm{C}$ until assayed. Analysis of fatty acids was made by gas chromatography (RuizGutierrez et al. 1992). The samples were saponified by heating for $5 \mathrm{~min}$ with $5 \mathrm{ml}$ of $0.2 \mathrm{M}$ sodium methylate and heated again at $80^{\circ} \mathrm{C}$ for 5 min with $6 \%$ (w/v) $\mathrm{H}_{2} \mathrm{O}$ in anhydrous methanol. The fatty acid methyl esters thus formed were eluted with n-hexane and analyzed in a Hewlett-Packard 5890 series II gas chromatograph equipped with a flame ionization detector and using an Omegawax 320 fused silica capillary column (30 m $\times$ $0.32 \mathrm{~mm}$ i.d., $0.25 \mathrm{pm}$ film). The initial column temperature was $200^{\circ} \mathrm{C}$, held for $10 \mathrm{~min}$, then programmed from 200 to $230^{\circ} \mathrm{C}$ at $2^{\circ} \mathrm{C} \mathrm{min}^{-1}$. The injection and detector temperatures were 250 and $260^{\circ} \mathrm{C}$, respectively.

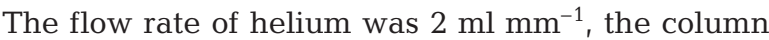
head pressure was $250 \mathrm{kPa}$, and the detector auxiliary flow rate was $25 \mathrm{ml} \mathrm{min}^{-1}$. Peak areas were calculated with a Hewlett-Packard 3390A recording integrator. Individual fatty acid methyl esters were identified on isothermal runs by comparison with standards. Fatty acid methyl esters for which no standard was available were quantified using calibration tables of relative response ratios constructed according to carbon number, using gas chromatography-mass spectrometry
(GC-MS). GC-MS was done on a Konik KNK-200 chromatograph interfaced directly to an AEI MS30/70 VG mass spectrometer, using the electron impact mode. The ion source temperature was maintained at $200^{\circ} \mathrm{C}$, multiplier voltage was $4.0 \mathrm{kV}$, emission current was $100 \mathrm{pA}$ and electron energy was $70 \mathrm{eV}$. The data were processed with a VG 11/250 data system.

Microalgal extraction and NMR analysis. To detect PUSCAs, frozen pellets of Alexandrium tamarense $\left(1.3 \times 10^{7}\right.$ cells, $\left.5 \mathrm{~g}\right)$ and Skeletonema costatum $(5.4 \times$ $10^{9}$ cells, $4.7 \mathrm{~g}$ ) were extracted as follows. Microalgae were suspended in $5 \mathrm{ml}$ of distilled water and sonicated for $1 \mathrm{~min}$ at $4^{\circ} \mathrm{C}$. The suspension was kept at room temperature for $30 \mathrm{~min}$ after which $5 \mathrm{ml}$ acetone was added. The sample was sonicated again for $1 \mathrm{~min}$ and then centrifuged for $5 \mathrm{~min}$ at $1400 \times g$. The supernatant was transferred to a separatory funnel, diluted with distilled water to a final volume of $20 \mathrm{ml}$, and partitioned $3 \times$ against dichloromethane $(15 \mathrm{ml})$. The organic layers were combined, dried over anhydrous $\mathrm{Na}_{2} \mathrm{SO}_{4}$, filtered on paper and concentrated at reduced pressure $\left(\mathrm{CH}_{2} \mathrm{Cl}_{2}\right.$ soluble material). The water phase was added to the sediment obtained from the centrifugation. The resulting mixture was suspended in $\mathrm{MeOH}$ and then sonicated for $30 \mathrm{~s}$. The hydro-alcoholic suspension was filtered on paper. The residue was washed with $\mathrm{MeOH}$ $(10 \mathrm{ml})$. The combined filtrates were transferred to a conical flask and concentrated at reduced pressure. The viscous residue was diluted with water $(9 \mathrm{ml})$ and partitioned between water, $\mathrm{MeOH}(12 \mathrm{ml})$ and $\mathrm{CHCl}_{3}$ $(24 \mathrm{ml})$. The lower layer was recovered and the water phase (upper layer) was processed in the same way twice again. The organic layers were combined and concentrated at reduced pressure $\left(\mathrm{CHCl}_{3}-\mathrm{MeOH}\right.$ soluble material). An aliquot of methanolic extract was fractionated in $100 \%$ methanol using a Sephadex LH-20 resin. The resulting fractions were tested for biological activity (see next section). The remaining methanolic extract was added to the $\mathrm{CH}_{2} \mathrm{Cl}_{2}$ soluble material to yield $35.7 \mathrm{mg}$ of extract from Skeletonema costatum and $45.6 \mathrm{mg}$ from Alexandrium tamarense. S. costatum cultures were grown under the same experimental conditions as $A$. tamarense except that the growth medium was $f / 2$ (Guillard \& Ryther 1962).

The combined extracts were analysed by ${ }^{1} \mathrm{H}-\mathrm{NMR}$ carried out on a Bruker Avance DRX at $400 \mathrm{MHz}$. For the analysis, octadienal and microalgal extracts were dissolved in $0.5 \mathrm{ml} \mathrm{CDCl}_{3}$. Spectra (32 Kbyte) were acquired between 12 and 0 ppm, with an interval delay of $3 \mathrm{~s}$ and 512 scans. $\mathrm{CHCl}_{3}$ was used as internal standard at $7.26 \mathrm{ppm}$.

Sea urchin bioassays. Sea urchins Sphaerechinus granularis were collected by SCUBA diving in the Gulf of Naples and transported to the laboratory. The urchins were injected with $0.5 \mathrm{M} \mathrm{KCl}$ to induce gamete 
ejection; spawned eggs were washed $3 \times$ with $0.22 \mu \mathrm{m}$ FSW and diluted to a final concentration of 3000 eggs $\mathrm{ml}^{-1}$. Concentrated sperm was collected in Eppendorf tubes and $10 \mu \mathrm{l}$ was diluted in $10 \mathrm{ml}$ of FSW just prior to fertilization. Decadienal solution was prepared by dissolving the commercial aldehyde (SIGMA-Aldrich) in ethanol to a concentration of $0.2 \mathrm{mg} \mathrm{ml}^{-1}$. Alexandrium tamarense extract prepared as described above, was initially dissolved in methanol and then transferred to FSW to give a stock solution of $0.2 \mathrm{mg} \mathrm{ml}^{-1}$. Serial dilutions were prepared to give the required experimental concentrations. Approximately 200 oocytes were stocked in 12-well microplates containing $1 \mathrm{ml}$ of medium: FSW alone, solvent blank, and A. tamarense extract or decadienal at set concentrations ranging from 0.3 to $5 \mu \mathrm{g} \mathrm{ml}^{-1}$. After $30 \mathrm{~min}$ incubation, oocytes were rinsed 3 times with FSW and fertilized by adding $10 \mu \mathrm{l}$ of sperm solution. Another group of approximately 200 oocytes were fertilized and transferred soon after in 12-well microplates containing set concentrations of $A$. tamarense and $S$. costatum extracts to test for anti-mitotic activity. Controls and solvent blank were included in all trials. Fertilization success and anti-mitotic activity were determined using an inverted microscope (Axiovert 25, Zeiss) and defined, respectively, as percentage of eggs showing complete elevation of the fertilization membrane, and percentage of first cleavage.

\section{RESULTS}

The toxin profile for the Alexandrium tamarense strain showed that it was non-neurotoxic with a PSP toxin content of $0.005 \pm 0.002 \mathrm{fmol} \mathrm{cell}^{-1}$ (mean $\pm \mathrm{SD}_{\text {; }}$

Table 1. Alexandrium tamarense. Fatty acid composition (mean weight percentage of total lipids) and amino acid composition (mean weight percentage of total amino acid yield)

\begin{tabular}{|lrlr|}
\hline Fatty acids & Percent & Amino acids & Percent \\
\hline 14:0 & 1.1 & Aspartic acid & 8.1 \\
$14: 1 \omega 5$ & 1.1 & Serine & 6.6 \\
$16: 0$ & 35.8 & Glutamic acid & 11.4 \\
$16: 1 \omega 9$ & 1.8 & Glycine & 10.5 \\
$18: 0$ & 4.3 & Histidine & 1.2 \\
$18: 1 \omega 9$ & 10.3 & Arginine & 6.2 \\
$18: 1 \omega 7$ & 3.4 & Threonine & 6.1 \\
$22: 0$ & 10.2 & Alanine & 12.2 \\
$20: 5 \omega 6$ & 2.8 & Proline & 6.2 \\
$20: 5 \omega 3$ & 3.0 & Tyrosine & 1.3 \\
& & Valine & 6.1 \\
& & Lysine & 6.4 \\
& & Isoleucine & 4.3 \\
& & Leucine & 9.3 \\
& & Phenylalanine & 3.8 \\
\hline
\end{tabular}
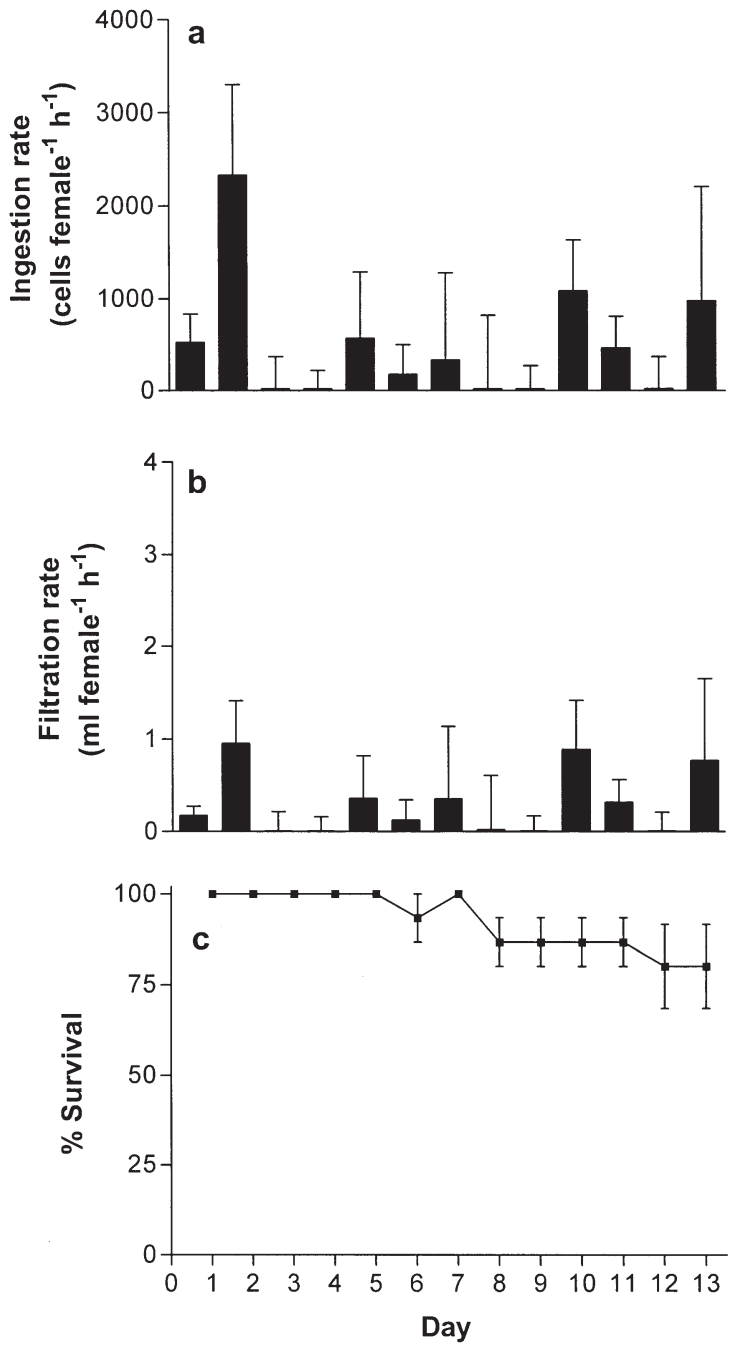

Fig. 1. Temora stylifera. (a) Ingestion rates, (b) filtration rates, (c) female survival (\%) in copepods offered unialgal cultures of a non-neurotoxic strain of the dinoflagellate Alexandrium tamarense for $13 \mathrm{~d}$ (mean $\pm \mathrm{SD}$ of 3 replicates)

data not shown). The amino acid composition of $A$. tamarense (Table 1) was similar to other non-neurotoxic phytoplankton species (Guisande et al. 1999). The diversity of fatty acids in $A$. tamarense was low compared to other phytoplankton species (Brown et al. 1997), but the content in eicosapentaenoic acid (EPA, $20: 5 \omega 3)$, which is essential for a variety of marine and freshwater zooplankton (DeMott \& Müller-Navarra 1997), was high. The fatty acid content of the control diet Prorocentrum minimum is very similar (Laabir et al. 2001).

Temora stylifera fed willingly on Alexandrium tamarense, with ingestion rates comparable to other diets in similar laboratory experiments (Turner et al. 2001). On a day-to-day basis, there was considerable variability in copepod feeding rates over $13 \mathrm{~d}$. Daily mean ingestion rates (Fig. 1a) ranged from 0 to 


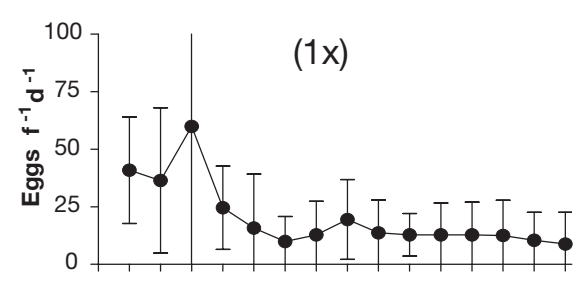

T. stylifera in A. tamarense EXPO
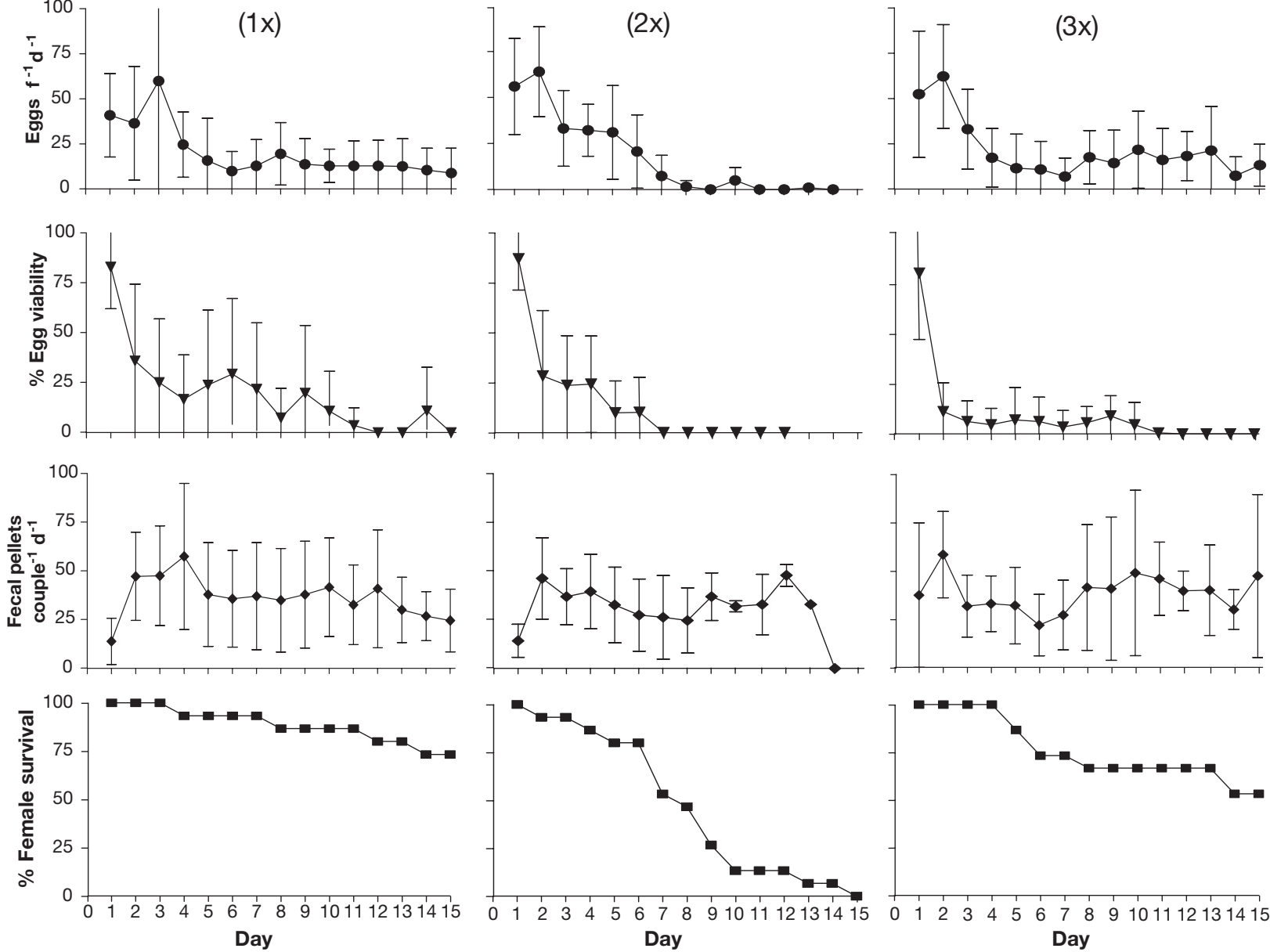

Fig. 2. Temora stylifera. Egg production rates per female $\left(\mathrm{f}^{-1} \mathrm{~d}^{-1}\right)$, egg viability (\% hatching), fecal pellet production (no. couple ${ }^{-1}$ $\mathrm{d}^{-1}$ ) and female survival $(\%)$ in copepods offered unialgal exponential phase cultures of a non-neurotoxic strain of the dinoflagellate Alexandrium tamarense at cell concentrations of $1 \times, 2 \times$ and $3 \times$ initial concentrations

Table 2. Temora stylifera. ANOVA repeated measures results on egg production (eggs female ${ }^{-1} \mathrm{~d}^{-1}$ ), egg viability $(\%)$, fecal pellet production (no. couple ${ }^{-1} \mathrm{~d}^{-1}$ ) and survival (\%) during $14 \mathrm{~d}$ feeding on exponential and stationary cultures of Alexandrium tamarense at $1 \times, 2 \times$ and $3 \times$ the initial cell concentration. Treatments with the same letter are not significantly different

\begin{tabular}{|c|c|c|c|c|}
\hline & $\begin{array}{c}\text { Egg } \\
\text { production }\end{array}$ & $\begin{array}{c}\text { Egg } \\
\text { viability }\end{array}$ & $\begin{array}{c}\text { Fecal pellet } \\
\text { production }\end{array}$ & Survival \\
\hline \multicolumn{5}{|c|}{ Exponential } \\
\hline $1 \times$ & A & $\mathrm{A}$ & $\mathrm{A}, \mathrm{B}$ & $\mathrm{A}$ \\
\hline $2 \times$ & A & $\mathrm{A}, \mathrm{B}$ & $\mathrm{A}, \mathrm{B}$ & $\mathrm{C}$ \\
\hline $3 \times$ & A & B & A & $\mathrm{A}, \mathrm{B}$ \\
\hline \multicolumn{5}{|c|}{ Stationary } \\
\hline $1 \times$ & $\mathrm{A}, \mathrm{B}$ & B & $\mathrm{A}, \mathrm{B}$ & B \\
\hline $2 \times$ & B & B & $\mathrm{A}, \mathrm{B}$ & $\mathrm{C}$ \\
\hline $3 \times$ & $\mathrm{A}, \mathrm{B}$ & B & B & $\mathrm{C}$ \\
\hline \multicolumn{5}{|c|}{ ANOVA } \\
\hline$F$ & $F_{5,13}=5.29$ & $F_{5,11}=8.13$ & $F_{5,13}=3.44$ & $F_{5,14}=28.77$ \\
\hline $\mathrm{p}$ & $<0.001$ & $<0.001$ & $<0.01$ & $<0.001$ \\
\hline
\end{tabular}

2333 cells female $\mathrm{e}^{-1} \mathrm{~h}^{-1}$ (mean: 498 cells female ${ }^{-1} \mathrm{~h}^{-1}$ ), and daily filtration rates (Fig. 1b) ranged from 0 to $0.955 \mathrm{ml} \mathrm{female}^{-1} \mathrm{~h}^{-1}$ (mean: $0.306 \mathrm{ml}$ female ${ }^{-1} \mathrm{~h}^{-1}$ ). Daily mean ingestion rates, converted to carbon equivalents ranged from 0 to $4.31 \mu \mathrm{gC}$ female ${ }^{-1} \mathrm{~h}^{-1}$ (mean $=$ $0.92 \mu \mathrm{gC}$ female ${ }^{-1} \mathrm{~h}^{-1}$ ). Copepod survival in grazing experiments was high, with daily means of $80 \%$ of the females surviving after $13 \mathrm{~d}$ (Fig. 1c).

In all experiments fecundity diminished rapidly with time; by the end of the experiments, egg production rates were $<25 \%$ of initial values (Figs. $2 \& 3$ ). Timecourses of egg production rates were similar in females fed exponential (EXPO) or stationary (STAT) cultures (except for STAT $2 \times$ ); there were no appreciable differences in egg production rates at increasing food concentrations (Table 2). Egg viability diminished with time in all experiments, and in the EXPO cultures there was a progressive reduction in egg viability from $1 \times$ to $2 \times$ to $3 \times$ initial cell concentrations (Fig. 2, Table 2). Viability in STAT cultures was lower than in 

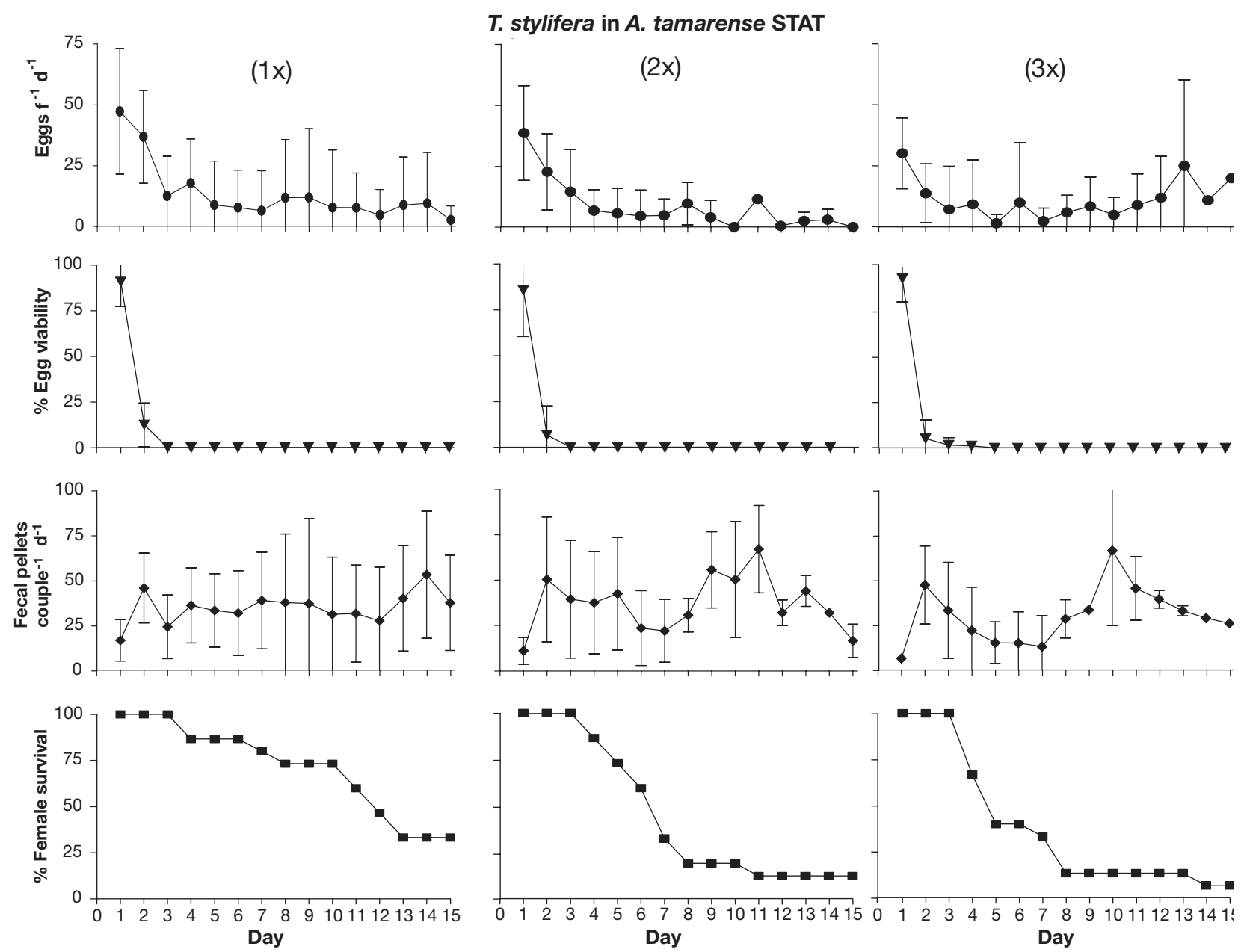

Fig. 3. Temora stylifera. Egg production rates per female $\left(\mathrm{f}^{-1} \mathrm{~d}^{-1}\right)$, egg viability (\% hatching), fecal pellet production (no. couple ${ }^{-1}$ $\mathrm{d}^{-1}$ ) and female survival (\%) in copepods offered unialgal stationary phase cultures of a non-neurotoxic strain of the dinoflagellate Alexandrium tamarense at cell concentrations of $1 \times, 2 \times$ and $3 \times$ initial concentrations

EXPO $1 \times$, but similar to EXPO $2 \times$ and $3 \times($ Table 2$)$, and dropped to $0 \%$ after only $24 \mathrm{~h}$ of feeding at all 3 algal concentrations (Fig. 3).

Fecal pellet production was generally high and constant with time in both EXPO and STAT cultures, and there were no appreciable differences between low $(1 \times)$ and high $(2 \times$ and $3 \times)$ cell concentrations, indicating that $A$. tamarense was grazed intensively (Figs. 2 \& 3 , Table 2). Copepod survival in egg production experiments decreased rapidly with time; $<50 \%$ of the females survived to Day 15, except at the lowest concentration (1×) EXPO culture. Survival was generally higher in the EXPO than STAT cultures, except for the intermediate concentration $(2 \times)$ EXPO culture, where all females were dead by Day 15 (Figs. 2 \& 3, Table 2). Spermatophore production (not shown) was stable over time and similar to values in other dinoflagellates (Ianora et al. 1999).

When fed with the control food Prorocentrum minimum, Temora stylifera showed very high egg produc- tion rates, which were stable with time, with average values of 61.5 eggs female ${ }^{-1} \mathrm{~d}^{-1}$ (Fig. 4). Moreover, the time-course fecundity with this control diet was higher than with Alexandrium tamarense STAT $1 \times$ (paired $t$-test, $\left.t_{14}=11.85, \mathrm{p}<0.001\right)$. Egg hatching success of females fed $P$. minimum was extremely high (>90\%) throughout the $15 \mathrm{~d}$ experimental period. Copepods showed very high initial fecal pellet production (>80 pellets couple ${ }^{-1} \mathrm{~d}^{-1}$ ), which decreased after the first day of feeding and remained constant thereafter. This trend was not different from the daily number of fecal pellets produced with a diet of $A$. tamarense (paired $t$-test, $t_{14}=0.46, \mathrm{p}>0.05$ ). Copepod survival was always $>90 \%$ for the entire period (Fig. 4 ).

To test for the presence of compounds responsible for reduced egg production and hatching success, raw lipophilic extracts of Alexandrium tamarense were obtained by successively preparing dichloromethane and chloroform-methanol soluble fractions; these were compared by ${ }^{1} \mathrm{H}-\mathrm{NMR}$ analysis to those obtained with 


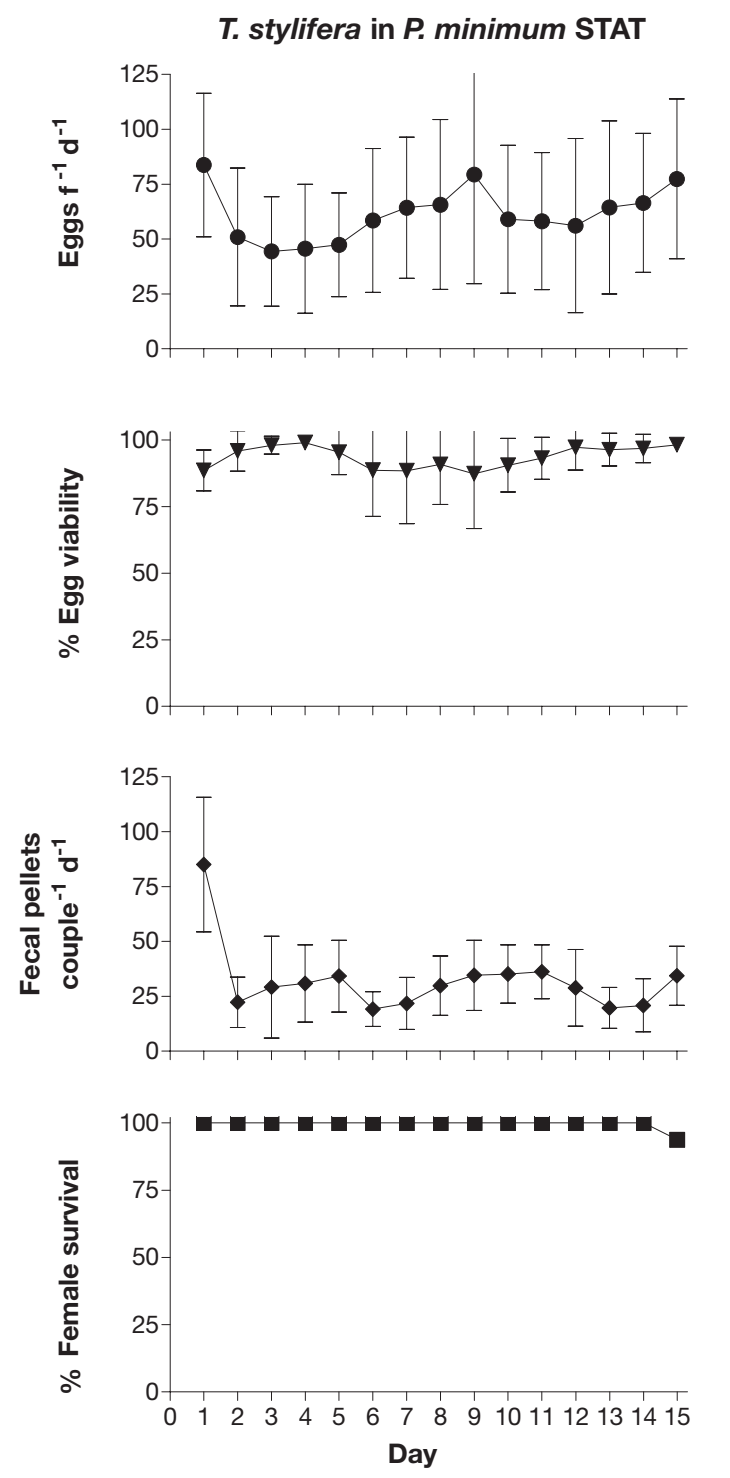

Fig. 4. Temora stylifera. Egg production rates per female $\left(\mathrm{f}^{-1} \mathrm{~d}^{-1}\right)$, egg viability (\%), fecal pellet production (no. couple ${ }^{-1}$ $\mathrm{d}^{-1}$ ) and female survival (\%) in copepods offered unialgal stationary phase cultures of the dinoflagellate Prorocentrum minimum

the diatom Skeletonema costatum, which has been shown to produce a number of PUSCAs (d'Ippolito et al. 2002, 2003). Commercial octadienal (isomeric mixture of $5 \%$ cis and $95 \%$ trans) was used as a standard (Fig. 5, top). Examination of ${ }^{1} \mathrm{H}-\mathrm{NMR}$ spectra of combined extract of $A$. tamarense (Fig. 5 bottom) unambiguously showed the absence of PUSCA signals at $\delta 9.62$ (d), 9.53 (d), 7.69 (dd), 7.34 (dd), 6.45 (d), 6.43 (d), 6.20 (dd) 6.12 (dd), which are evident in the $S$. costatum combined extract (Fig. 5 center) (where $\delta=$ chemical shift, $\mathrm{d}=$ doublet, $\mathrm{dd}=$ double doublet).

Alexandrium tamarense also differed from PUSCAs in terms of biological activity in the sea urchin bioassay (e.g. Pagano et al. 1986). Of the 2 organic extracts of $A$. tamarense, the one obtained in $\mathrm{MeOH}$ was the more active and one of the fractions obtained by its separation on Sephadex LH-20 resin blocked fertilization of sea urchin oocytes at concentrations of $1 \mu \mathrm{g} \mathrm{ml}^{-1}$; decadienal, a commercially available PUSCA, had little or no effect on fertilization success at any of the concentrations tested (Fig. 6). By contrast, the A. tamarense active fraction had little or no effect on sea urchin firstcell cleavage as opposed to decadienal, which blocked cell cleavage at concentrations of $1 \mu \mathrm{g} \mathrm{ml}^{-1}$, confirming previous studies on the anti-mitotic activity of this aldehyde (d'Ippolito et al. 2002).

\section{DISCUSSION}

Even though the dinoflagellate clone used in the present study was 'non-toxic' in that it did not contain saxitoxins or neosaxitoxins, Alexandrium tamarense nonetheless produced deleterious effects on reproduction and survival of the copepod Temora stylifera. These effects included reduced egg production rates and hatching success. They were not due to reduced grazing, since copepods seemed to feed well upon the dinoflagellate even though there was large variability in daily ingestion rates (possibly due to high algal concentrations). Egg production rates reported here ranged from mean values of 4.3 to 21.7 eggs female ${ }^{-1}$ $\mathrm{d}^{-1}$, which are much lower than those reported for $T$. stylifera when it feeds on other flagellate and diatom species (Ianora et al. 1999, Turner et al. 2001, Ceballos \& Ianora 2003). In these previous studies, the highest egg production rates for $T$. stylifera feeding on the dinoflagellates Gonyaulax polyedra and Prorocentrum minimum for $14 \mathrm{~d}$ were 55 and 58 eggs female ${ }^{-1} \mathrm{~d}^{-1}$, respectively. Similar values were found in the present study with the control $P$. minimum diet. These results indicate that although $A$. tamarense was 'non-toxic', there were other biochemical characteristics of the food that negatively affected egg production rates in T. stylifera.

Similar results have been reported by Dutz (1998), who found a reduction of copepod fecundity in Acartia clausi females exposed to the neurotoxic dinoflagellate Alexandrium lusitanicum. At concentrations of 1.25 and 1.56 saxitoxin $_{\mathrm{eq}}$ cell-1, A. clausi fed on toxic cells at high rates without effects on copepod survival, but egg production was limited over the range of food concentrations offered. Dutz suggested that the toxins possibly interfered with digestive processes or caused enhanced energy expenditure due to detoxification, resulting in reduced female fecundity.

Reduced egg production rates with Alexandrium tamarense occurred even though females fed well on 

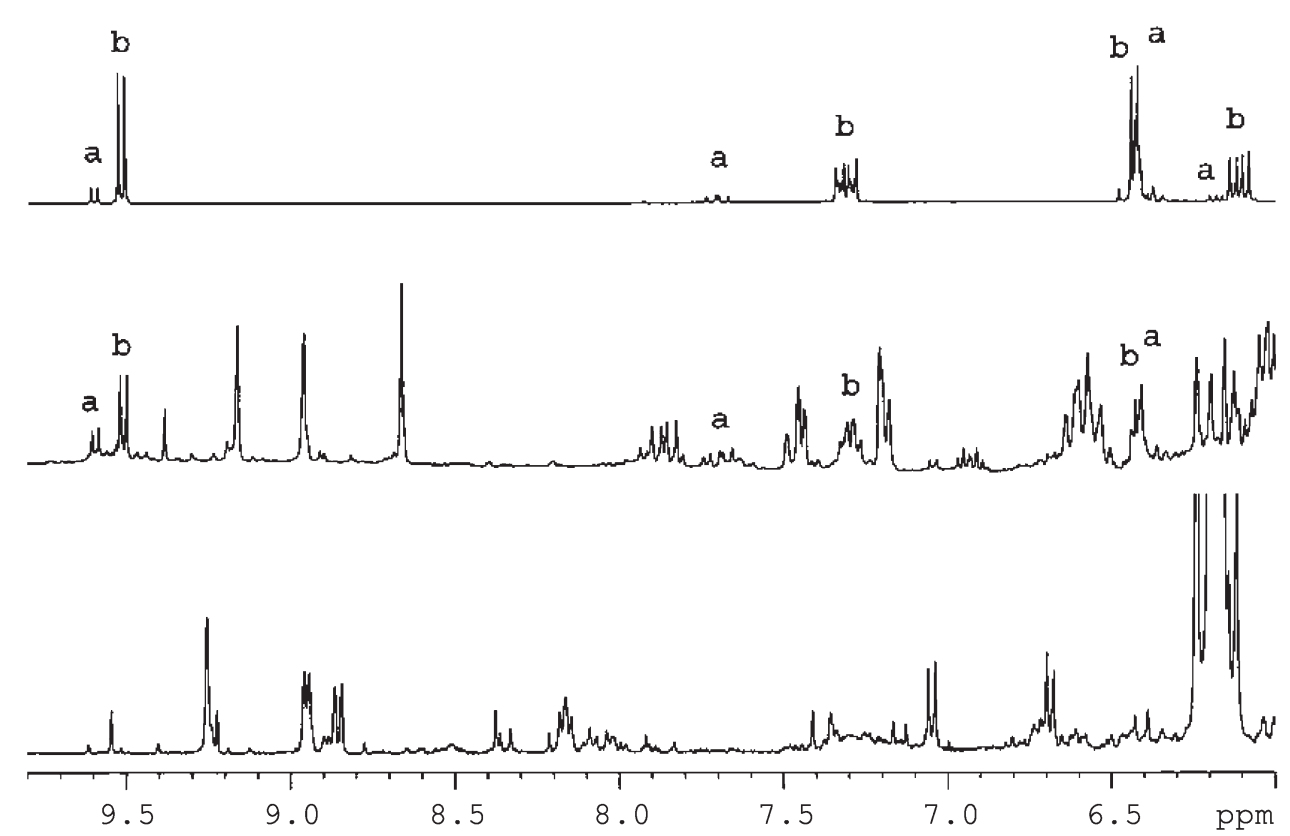

Fig. 5. Downfield region (9.80-6.00 ppm) of the ${ }^{1} \mathrm{H}-\mathrm{NMR}$ spectra of lipophilic extracts. Top: commercially available 2,4-octadienal, center: Skeletonema costatum; bottom: Alexandrium tamarense. Isomers of octadienal: (a) trans--, cis-; (b) trans-, trans-

this dinoflagellate. In fact, ingestion and filtration rates were similar or even higher than those recorded for Temora stylifera feeding on diets of the dinoflagellate Prorocentrum minimum (Turner et al. 2001). Thus, we found the same reduced fecundity on dinoflagellate diets as reported by Dutz (1998), although he attributed it to saxitoxins, whereas we found that the same effect occurred even when saxitoxins were not present. Hence, such adverse effects on grazers of 'toxic' dinoflagellates may be due to known neurotoxins such as saxitoxins, or to less obvious or unknown compounds.

The reduction of egg hatching success was even more dramatic. In stationary cultures, egg viability was reduced to zero as quickly as $24 \mathrm{~h}$ after feeding on Alexandrium tamarense at all 3 algal concentrations tested. This was much faster than observed for several species of copepods feeding on various diatoms, where hatching success became reduced after 5 to $10 \mathrm{~d}$ of feeding (Poulet et al. 1995, Uye 1996, Turner et al. 2001, Ceballos \& Ianora 2003, Ianora et al. 2003). This reduction was not likely due to a nutritional deficiency since $A$. tamarense did not seem to lack any essential amino acids and fatty acids (Table 1). A deficiency in any essential compound in the food will usually produce a negative effect on copepod reproduction after 2 to $3 \mathrm{~d}$ (Kleppel et al. 1988, Guisande et al. 1999), and hatching success will decline to $30 \%$, but not to $0 \%$.

If saxitoxins or a nutritional deficiency were not responsible for reduced egg production and hatching success, then what was the cause? Diatom-derived aldehydes were not responsible for adverse effects on hatching, since PUSCAs were absent in Alexandrium tamarense as compared to the diatom Skeletonema costatum. Diatom PUSCAs include a number of mole-
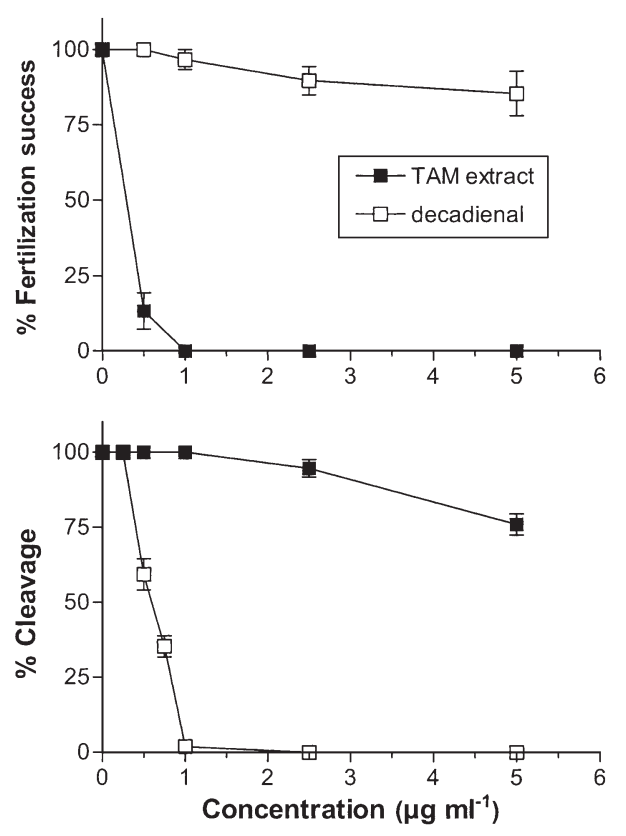

Fig. 6. Sphaerechinus granularis. Sea urchin bioassays comparing the effects of lipophilic extracts of the dinoflagellate Alexandrium tamarense (TAM) and the diatom-derived aldehyde decadienal 
cules sharing the presence of an $\alpha, \beta$-unsaturated aldehydic function that is believed to be necessary for the biological activity of these molecules (Adolph et al. 2003). This functional group is easy to detect by proton magnetic resonance spectroscopy $\left({ }^{1} \mathrm{H}-\mathrm{NMR}\right)$ since it gives rise to a diagnostic signal in the downfield region of the spectrum (Fig. 5). These NMR signals are rather independent of the parts of the molecule that do not affect the chemical shift and multiplicity of the lines. As shown in Fig. 5, the NMR spectra of raw extracts of $A$. tamarense did not reveal any presence of such spectroscopic markers, which on the other hand were clearly discernible in the raw material obtained from the PUSCA-producing diatom S. costatum (d'Ippolito et al. 2002). This indicates that toxic aldehydes either do not occur in the dinoflagellate or are present at significantly lower levels than those recorded in diatoms.

Until now, diatom-derived PUSCAs are the only compounds that have been shown to block mitotic divisions in copepod embryos (Miralto et al. 1999, Ianora et al. 2003 and references therein). However, there are several examples of other compounds isolated from marine dinoflagellates that block cell division in the classic sea urchin bioassay. These include goniodomin-A from Goniodoma pseudogoniaulax (Murakami et al. 1988), amphidinolide-A from Amphidinium sp. (Kobayashi et al. 1986), and okadaic acid and its derivative dinophysistoxin-1, which are common in some species of the genera Prorocentrum and Dinophysis, respectively (Fujiki et al. 1988). Extracts of Alexandrium tamarense may also inhibit egg hatching and larval survival in the scallop Chlamys farreri (Yan et al. 2001). In all of these studies, the molecules or extracts tested showed anti-mitotic activity with blockage of cell divisions in developing sea urchin embryos. In the present study, however, there was little or no adverse effect on cell cleavage, but very strong effects on fertilization success when oocytes were incubated for $30 \mathrm{~min}$ in $A$. tamarense extracts. A reduction in fertilization capacity has been found for Temora stylifera fed with the dinoflagellates Prorocentrum micans, Akashiwo sanguinea and Lingulodinium polyedra (Ianora et al. 1999); however, this effect was due to an inability of sperm to fertilize the oocytes, whereas in the present study an absence of fertilization success was likely due to alterations in the fertilization membrane of female gametes, preventing the sperm from penetrating the oocyte.

Stationary phase cultures generally induced stronger effects on egg production and hatching success than exponential cultures, with hatching success dropping to $0 \%$ at all 3 algal concentrations tested. This indicates that the unidentified compounds were being pro- duced in greater quantities in older cultures, as is the case for domoic acid production in Pseudo-nitzschia multiseries (Bates 1998). Clearly, these compounds were not feeding deterrents since Temora stylifera fed well on this Alexandrium tamarense strain, with fecal pellet production rates comparable to other dinoflagellate (Lingulodinium polyedrum and Prorocentrum minimum) and flagellate (Isochrysis galbana) diets (Ianora et al. 1999). Carbon equivalent ingestion rates were also high in comparison to those of our previous studies, although food concentrations were also comparatively high. Nonetheless, there were adverse effects on other life history parameters such as fecundity, egg viability and adult female survivorship, even though such effects are probably attenuated during natural $A$. tamarense blooms since the algal concentrations tested here are $5 \times$ greater than in situ.

Why do microalgae produce such compounds if they do not serve to deter feeding in their predators? According to chemical defense theory, there should be a selective survival advantage for species that can 'protect' themselves from grazers, allowing such species to grow explosively, because the growth of the populations of their predators has been suppressed. This could occur through the production of chemicals that not only deter feeding activity, but also reduce population growth. For example, reactive aldehydes of diatoms reduce egg production and/or hatching success, thereby sabotaging copepod population growth and, consequently, predator grazing impact. In the case of Alexandrium tamarense, the defense machinery is potentially even more effective, because female longevity is reduced as well.

A paradox of dinoflagellate toxins such as the saxitoxins is that they primarily poison organisms that are not the direct grazers of the dinoflagellates, such as fish, marine mammals and birds, and humans (reviewed by Turner \& Tester 1997, Cembella 2003). These toxins often have little or no adverse effects on direct dinoflagellate grazers such as copepods and other zooplankton organisms. Thus, an antipredation role of dinoflagellate toxins might serendipitously favor grazers rather than dinoflagellates, since copepods may sequester these compounds from dinoflagellates (Turner et al. 2000, Tester et al. 2001), and ingested toxins possibly act as defenses to deter predation on copepods by fish and other zooplanktivorous consumers. Conversely, dinoflagellates may produce metabolites, other than reactive aldehydes, that directly impact predator fitness by reducing fertilization capacity. Although the chemical nature of these molecules remains elusive, our findings indicate that as in the case of diatoms, dinoflagellates may produce antiproliferative compounds which can suppress copepod population growth. 
Acknowledgements. We thank Mario Di Pinto and Massimo Perna for technical assistance, Javier Sanchez for the fatty acid analyses and Flora Palumbo for computer graphics.

\section{LITERATURE CITED}

Adolph S, Poulet SA, Pohnert G (2003) Synthesis and biological activity of $\alpha, \beta, \gamma, \delta$-unsaturated aldehydes from diatoms. Tetrahedron 59:3003-3008

Baden DG, Trainer VL (1993) Mode of action of toxins of seafood poisoning. In: Falconer IR (ed) Algal toxins in seafood and drinking water. Academic Press, San Diego, p 49-47

Ban S, Lee HW, Shinada A, Toda T (2000) In situ egg production and hatching success of the marine copepod Pseudocalanus newmani in Funka Bay and adjacent waters off south-western Hokkaido, Japan: association to diatom bloom. J Plankton Res 22:907-922

Bates SS (1998) Ecophysiology and metabolism of ASP toxin production. In: Anderson DM, Cembella AD, Hallegraeff GM (eds) Physiological ecology of harmful algal blooms. NATO ASI Series G, Ecological sciences, Vol 41. SpringerVerlag, Berlin, p 405-426

Brown MR, Jeffrey SW, Volkman JK, Dunstan GA (1997) Nutritional properties of microalgae for mariculture. Aquaculture 151:315-331

Ceballos S, Ianora A (2003) Different diatoms induce contrasting effects on the reproductive success of the copepod Temora stylifera. J Exp Mar Biol Ecol 294:189-202

Cembella AD (1998) Ecophysiology and metabolism of paralytic shellfish toxins in marine microalgae. In: Anderson DM, Cembella AD, Hallegraeff GM (eds) Physiological ecology of harmful algal blooms. NATO ASI Series G, Ecological Sciences, Vol 41. Springer-Verlag, Berlin, p 381-403

Cembella AD (2003) Chemical ecology of eukaryotic microalgae in marine ecosystems. Phycologia 42:420-447

DeMott WR, Müller-Navarra DC (1997) The importance of highly unsaturated fatty acids in zooplankton nutrition: evidence from experiments with Daphnia, a cyanobacterium and lipid emulsions. Freshw Biol 38:649-664

d'Ippolito G, Romano G, Iadicicco O, Miralto A, Ianora A, Cimino G, Fontana A (2002) New birth-control aldehydes from the marine diatom Skeletonema costatum. Tetrahedron Lett 43:6133-6136

d'Ippolito G, Romano G, Caruso T, Spinella A, Cimino G, Fontana A (2003) Production of octadienal in the marine diatom Skeletonema costatum. Org Lett 5:885-887

Doucette GJ, Kodama M, Franca S, Gallacher S (1998) Bacterial interactions with harmful algal bloom species: bloom ecology, toxigenesis, and cytology. In: Anderson DM, Cembella AD, Hallegraeff GM (eds) Physiological ecology of harmful algal blooms. NATO ASI Series G, Ecological Sciences, Vol 41. Springer-Verlag, Berlin, p 619-647

Dutz J (1998) Repression of fecundity in the neritic copepod Acartia clausi exposed to the toxic dinoflagellate Alexandrium lusitanicum: relationship between fecundity and egg production. Mar Ecol Prog Ser 175:97-107

Folch J, Lees M, Sloane-Stanley GH (1957) A simple method for the isolation and purification of total lipids from animal tissues. J Biol Chem 226:497-509

Franco JM, Fernández P (1993) Separation of PSP toxins by reverse phase high performance liquid chromatography, with postcolumn reaction and fluorometric detection. Chromatographia 35:613-620
Frangópulos M, Guisande C, Maneiro I, Riveiro I, Franco J (2000) Short-term and long-term effects of the toxic dinoflagellate Alexandrium minutum on the copepod Acartia clausi. Mar Ecol Prog Ser 203:161-169

Frost BW (1972) Effects of size and concentration of food particles on the feeding behavior of the marine planktonic copepod Calanus pacificus. Limnol Oceanogr 17:805-815

Fujiki H, Suganuma M, Suguri H, Yoshizawa S and 7 others (1988) Diarrhetic shelfish toxin, dinophysistoxin-1, is a potent tumor promoter on mouse skin. Jpn J Cancer Res 79:1089-1093

Guillard RRL (1973) Division rates. In: Stein JR (ed) Handbook of phycological methods. Cambridge University Press, Cambridge, p 289-311

Guillard RRL, Ryther JH (1962) Studies of marine planktonic diatoms: I. Cyclotella nana Husted and Detonula confervacea (Cleve) Gran. J Microbiol 8:229-239

Guisande C, Maneiro I, Riveiro I (1999) Homeostasis in the essential amino acid composition of the marine copepod Euterpina acutifrons. Limnol Oceanogr 44:691-696

Guisande C, Frangópulos M, Carotenuto Y, Maneiro I, Riveiro I, Vergara AR (2002) Fate of paralytic shellfish poisoning toxins ingested by the copepod Acartia clausi. Mar Ecol Prog Ser 240:105-115

Huntley ME, Sykes P, Rohan S, Marin V (1986) Chemicallymediated rejection of dinoflagellate prey by the copepods Calanus pacificus and Paracalanus parvus: mechanisms, occurrence and significance. Mar Ecol Prog Ser 28: $105-120$

Huntley ME, Ciminiello P, Lopez MDG (1987) Importance of food quality in determining development and survival of Calanus pacificus (Copepoda: Calanoida). Mar Biol 95: 103-113

Ianora A, Miralto A, Buttino I, Poulet SA, Romano G (1999) First evidence of some dinoflagellates reducing male copepod fertilization capacity. Limnol Oceanogr 44: 147-153

Ianora A, Poulet SA, Miralto A (2003) The effects of diatoms on copepod reproduction: a review. Phycologia 42: 351-363

Ianora A, Miralto A, Poulet SA, Carotenuto Y and 8 others (2004) Aldehyde suppression of copepod recruitment in blooms of a ubiquitous planktonic diatom. Nature 429: 403-407

Irigoien $\mathrm{X}$, Harris RP, Verheye HM, Joly $\mathrm{P}$ and 14 others (2002) Copepod hatching success in marine ecosystems with high diatom concentrations. Nature 419:387-389

Keller MD, Selvin RC, Claus W, Guillard RRL (1987) Media for the culture of oceanic ultraphytoplankton. J Phycol 23: $633-638$

Kleppel GS, Frazel D, Pieper RE, Holliday DV (1988) Natural diets of zooplankton off southern California. Mar Ecol Prog Ser 49:231-241

Kobayashi J, Ishibashi M, Nakamura H, Ohizumi Y, Yamasu T, Sasaki T, Hirata Y (1986) Amphidinolide-A, a novel antineoplastic macrolide from the marine dinoflagellate Amphidinium sp. Tetrahedron Lett 27:5755-5758

Laabir M, Buttino I, Ianora A, Kattner G, Poulet SA, Romano G, Carotenuto Y, Miralto A (2001) Effect of specific dinoflagellate and diatom diets on gamete ultrastructure and fatty acid profiles of the copepod Temora stylifera. Mar Biol 138:1241-1250

Miralto A, Barone G, Romano G, Poulet SA and 7 others (1999) The insidious effect of diatoms on copepod reproduction. Nature 402:173-176

Miralto A, Guglielmo L, Zagami G, Buttino I, Granata A, Ianora A (2003) Inhibition of population growth in the 
copepod Acartia clausi and Calanus helgolandicus during diatom blooms. Mar Ecol Prog Ser 254:253-268

Murakami M, Makabe K, Yamaguchi K, Konosu S (1988) Goniodomin A, a novel polyether macrolide from the dinoflagellate Goiniodoma pseudogoniaulax. Tetrahedron Lett 29:1149-1152

Nejstgaard JC, Hygum BH, Naustvoll LJ, Båmstedt U (2001) Zooplankton growth, diet and reproductive success compared to simultaneous diatom- and flagellate-microzooplankton-dominated plankton blooms. Mar Ecol Prog Ser 221:77-91

Ohman MD, Hirche HJ (2001) Density-dependent mortality in an oceanic copepod population. Nature 412:638-641

Oshima Y (1995) Post-column derivization HPLC methods for paralytic shell fish poisons. In: Hallegraeff GM, Anderson DM, Cembella AD (eds) Manual on harmful marine microalgae. IOC Manuals and Guides No 33, UNESCO, Paris, p 81-94

Oshima Y, Sugino K, Yasumoto T (1989) Latest advances in HPLC analysis of paralytic shellfish toxins. In: Natori $\mathrm{S}$, Hashimoto K, Ueno Y (eds) Mycotoxins and phycotoxins. Elsevier, Amsterdam, p 319-326

Pagano G, Cipollaro M, Corsale G, Esposito A, Ragucci E, Giordano GG, Trieff NM (1986) The sea urchin bioassay testing the sublethal toxicity of realistic pollutant levels. In: Cairns J Jr (ed) Community toxicity testing. American Society for Testing and Materials, Philadelphia, p 67-92

Pohnert G (2000) Wound-activated chemical defense in unicellular planktonic algae. Angew Chem Int Ed Engl 39: 4352-4354

Pohnert G, Lumineau O, Cueff A, Adolph S, Cordevant C, Lang $M$, Poulet $S$ (2002) Are volatile unsaturated aldehydes from diatoms the main line of chemical defense against copepods? Mar Ecol Prog Ser 245:33-45

Poulet SA, Laabir M, Ianora A, Miralto A (1995) Reproductive response of Calanus helgolandicus. I. Abnormal embryonic and naupliar development. Mar Ecol Prog Ser 129:85-95

Rosahl S (1996) Lipoxygenases in plants - their role in development and stress response. Z Naturforsch 51c:123-138

Ruiz-Gutierrez V, Cert A, Rios JJ (1992) Determination of phospholipid fatty acid and triacylglycerol composition of rat caecal mucosa. J Chromatogr B 575:1-6

Strathmann RR (1967) Estimating the organic carbon content of phytoplankton from cell volume or plasma volume. Limnol Oceanogr 12:411-418

Sykes PF, Huntley MA (1987) Acute physiological reactions

Editorial responsibility: Otto Kinne (Editor),

Oldendorf/Luhe, Germany of Calanus pacificus to selected dinoflagellates: Direct observations. Mar Biol 94:19-24

Teegarden GJ (1999) Copepod grazing selection and particle discrimination on the basis of PSP toxin content. Mar Ecol Prog Ser 181:163-176

Tester PA, Turner JT, Shea D (2001) Vectorial transport of toxins from the dinoflagellate Gymnodinium breve through copepods to fish. J Plankton Res 22:47-61

Turner JT, Tester PA (1997) Toxic marine phytoplankton, zooplankton grazers, and pelagic food webs. Limnol Oceanogr 42:1203-1214

Turner JT, Tester PA, Hansen PJ (1998a) Interactions between toxic marine phytoplankton and metazoan and protistan grazers. In: Anderson DM, Cembella AD, Hallegraeff GM (eds) Physiological ecology of harmful algal blooms, NATO ASI Series G, Ecological Sciences, Vol 41. SpringerVerlag, Berlin, p 453-474

Turner JT, Lincoln JA, Cembella AD (1998b) Effects of toxic and non-toxic dinoflagellates on copepod grazing, egg production and egg hatching success. In: Reguera B, Blanco J, Fernandez ML, Wyatt T (eds) Harmful algae. Xunta de Galicia and IOC, UNESCO, Paris, p 379-381

Turner JT, Doucette GJ, Powell CL, Kulis DM, Keafer BA, Anderson DM (2000) Accumulation of red tide toxins in larger size fractions of zooplankton assemblages from Massachusetts Bay, USA. Mar Ecol Prog Ser 203:95-107

Turner JT, Ianora A, Miralto A, Laabir M, Esposito F (2001) Decoupling of copepod grazing rates, fecundity and egghatching success on mixed and alternating diatom and dinoflagellate diets. Mar Ecol Prog Ser 220:187-199

Uye S (1996) Induction of reproductive failure in the planktonic copepod Calanus pacificus by diatoms. Mar Ecol Prog Ser 133:89-97

Uye S, Takamatsu K (1990) Feeding interactions between planktonic copepods and red-tide dinoflagellates from Japanese coastal waters. Mar Ecol Prog Ser 59:97-107

Van Wandelen CH, Cohen SA (1997) Using quaternary highperformance liquid chromatography eluent systems for separating 6-aminoquinolyl-N-hydroxysuccinimidyl carbamate-derivatized amino acid mixtures. J Chromatogr A 763:11-22

Yan T, Mingjiang Z, Fu M, Wang Y, Yu R, Li J (2001) Inhibition of egg hatching success and larval survival of the scallop, Chlamys farreri, associated with exposure to cells and cell fragments of the dinoflagellate Alexandrium tamarense. Toxicon 39:1239-1244

Submitted: October 22, 2003; Accepted: August 5, 2004

Proofs received from author(s): September 6, 2004 